\title{
THE LIMITS OF REASON IN J.M. COETZEE'S THE SCHOOLDAYS OF JESUS
}

\section{LOS LÍMITES DE LA RAZÓN EN THE SCHOOLDAYS OF JESUS, DE J.M. COETZEE}

\author{
PATRICIA ÁLVAREZ SÁNCHEZ \\ Universidad de Málaga \\ patriciaalvarezsanchez@gmail.com
}

\begin{abstract}
This paper explores J.M. Coetzee's latest novel, The Schooldays of Jesus (2016), and focuses on its intense dialogue with ancient philosophical ideas such as Plato's Theory of Forms and some of the author's literary precursors, such as Cervantes' Don Quixote (1605) and Musil's The Confusions of Young Törless (1906). It is also a tribute to Johann Sebastian Bach's brilliant mind and music, which Coetzee has already commented upon on different occasions. The Schooldays is an intertextual story about the magic of numbers, dance and music and tells the story of Davíd, a rebellious child who is sent to Juan Sebastián Arroyo's Academy of Dance (Arroyo is Bach's name translated into Spanish), where he learns that music and dance can help us communicate with the universe and discover our true selves. It is the first time Coetzee incorporates magical elements and constant spiritual allusions in one of his plots, and I will argue that these, together with the intertextuality with other novels and texts and the characterization of the main characters, are used to show (once again) his ambivalence towards rationalism, but in a different style. This represents a turning point in his literary career.
\end{abstract}

Keywords: Coetzee, Don Quixote, intertextuality, irrationality, music. 


\section{Resumen}

Este artículo analiza la última novela de J.M. Coetzee, The Schooldays of Jesus (2016), y se concentra en el intenso diálogo que establece con ideas filosóficas antiguas, como la teoría de las ideas de Platón, y con algunos de sus precursores literarios, como Don Quijote (1605) de Miguel de Cervantes y The Confusions of Young Törless (1906) de Musil. The Schooldays of Jesus es también un tributo a la mente brillante y a la música de Johann Sebastian Bach, a quien Coetzee admira, como ha comentado en diferentes ocasiones. La novela, un ejemplo de intertextualidad que combina la magia de los números, la danza y la música, narra la historia de Davíd, un niño rebelde que cursa estudios de danza en la academia de baile de Juan Sebastián Arroyo (Johann Sebastian Bach traducido al español). Allí Davíd aprende que la música y el baile nos pueden ayudar a comunicarnos con el universo y a descubrirnos a nosotros mismos. Esta es la primera vez que Coetzee incorpora elementos mágicos y alusiones del mundo espiritual a uno de sus argumentos. En nuestra interpretación, argumentamos que estos elementos, la intertextualidad con otras obras literarias y la caracterización de los personajes principales son la forma que tiene Coetzee de mostrar su ambivalencia hacia el racionalismo, tal y como ha venido haciendo en todas sus novelas, pero que en esta ocasión representa un cambio significativo, ya que lo hace con un estilo nuevo.

Palabras clave: Coetzee, Don Quijote, intertextualidad, irracionalidad, música.

\section{Introduction}

Coetzee's novels are well known as illustrations of the excesses and consequences of the abuse of power and human suffering in many different ways. In them, the author portrays the psychological mechanisms which the characters develop in order to survive in the most extreme social circumstances of civil war, racism and complete isolation. These mechanisms often seem illogical and are linked to a moment of revelation that exposes the limited capacity of our reason to govern our lives. For instance, one of Coetzee's most powerful figures of Otherness, Michael $\mathrm{K}$ in Life \& Times of Michael $K$ (1983), refuses to participate in a civil war and isolates himself on a farm, where he hides in a hole and cultivates pumpkins. Thus, he finds a niche on the margins of society and refuses to eat for weeks, becoming undernourished and putting his life in danger. Another example is Mrs Curren in Age of Iron (1990). While she narrates the last months of her life in a letter to be sent to her daughter after her death, she witnesses the destruction of a township in front of her very eyes. We might conclude that it is precisely her perseverance and the writing of that letter that keep her alive: "Death may indeed be the last great 


\section{The Limits of Reason in J.M. Coetzee's The Schooldays of Jesus}

foe of writing, but writing is also the foe of death" (Coetzee 1990: 115-116). Mrs Curren makes the most irrational decision when she decides to trust a homeless man, Mr Vercueil, to post the letter for her. Moreover, Coetzee's probably most controversial novel Disgrace (1999) begins with the tribulations of David Lurie, a professor of Romantic poetry at Cape Technical University. Characterised as a "servant of Eros" (1999: 52), he forces one of his students into a sexual relationship, and gets dismissed from the university. Lurie retreats to his daughter's smallholding where she is gang raped. The protagonist, who justifies his actions by arguing that his temperament is fixed without alteration, learns to accept his disgraceful existence when he becomes aware of the suffering of the animals he begins to take care of and in connection with the opera on Byron he is trying to write; therefore, the novel seems to hold out hope that human beings "can awake from their moral immaturity" (Woessner 2010: 238). These are examples of how many of Coetzee's protagonists are brought to the limits of reason by unexpected events. In his two latest novels, The Childhood of Jesus (2013) and The Schooldays of Jesus (2016), he again approaches this idea but from an entirely different perspective, creating a place where there is, at least apparently, no power and no hierarchy of any kind.

When J.M. Coetzee moved from South Africa to Australia in 2002, the content and emphasis of his work also shifted. His novels continue to encourage readers to engage with difficult ethical questions, but the difference is that from Elizabeth Costello (2003) onwards, a new and more intense philosophical tone has emerged. ${ }^{1}$ Indeed, Elizabeth Costello contains philosophical lectures, and deals with the utmost importance of human attitudes towards animals, Slow Man (2005) focuses on the nature of care and emotions, and Coetzee's recently published collection of short stories Siete Cuentos Morales $(2018)^{2}$ features the character of Elizabeth Costello, who is an old woman facing death, and reveals different moral didactic purposes and the primacy of ethics in life.

Moreover, in spite of Plato's idea that literature cannot contribute to philosophical discussions, Coetzee's latest novels illustrate how philosophy and literature can find artistic expression in different narrative forms and constellations. As one of the most important founders of Western philosophy, Plato, who was influenced by Heraclitus, Pythagoras and Socrates, established the epistemological base for later philosophers and Christian theology; he also insisted that the world of intellect is separated from the world of senses. In fact, the traditional opposition of the rational and the mystical can be traced back to him, as he believed that reason was linked to theology and the divine. Before him, Pythagoras may have been the first philosopher to stress rationalist insight, as an enthusiast for the promotion of mathematical philosophy and the founder of mathematics; but he was also on the side of mysticism, believed in reincarnation and attributed to himself a semi-divine 


\section{Patricia Álvarez Sánchez}

character. He was indeed a very influential person in Ancient Greece and his opinions "were taken by his followers as sacred revelations" (Hermann 2004: 17). It is generally agreed that Pythagoras established the foundations of number theory, discovered the importance of numbers in music and believed that numbers were the key to all knowledge and that they may raise one's soul to a higher level of immortality (Ferguson 2011: 67). This is important in my interpretation of The Schooldays for the novel is an intense intertextual dialogue with some of Plato's and Pythagoras' philosophical ideas.

Pythagoras was Plato's main source of inspiration and Platonism is indeed in essence a version of Pythagoreanism (Russell 1972: 37). One of the most important contributions of Plato's philosophy is his Theory of Forms, which distinguishes between two levels of reality. ${ }^{3}$ Plato was also interested in numbers and believed that there are three stages in education, which correspond to the three virtues the soul should achieve: temperance, courage and wisdom. First, music serves to temper the desires of the heart; second, gymnastics should rationalise the passionate part of the soul; and third, mathematics trains the rational element of the soul to realise itself in the universal and eternal reality (Marshall 2016: 281). Having said that, it is important to remember that mathematics is one of Coetzee's specialisations and a subject he consciously pays a lot of attention to in The Schooldays of Jesus. While we tend to believe that it is a science which has links to reason, especially since the Enlightenment, a movement that emphasized the use of reason for obtaining knowledge and scrutinising ideas, Coetzee shows that even mathematics can go beyond reason, but as Woessner reminds us: "if we have forgotten that the Enlightenment rests on sentimental foundations as much as rational ones, it is because the scientific rationalism of the Enlightenment has had a much more lasting impact on the Western tradition” (2010: 236).

Having said that, Coetzee is well-known as one of the most cultured living writers and prominent literary critics, and his writings are so complex and significant that they have been discussed as an example of postmodernism, sometimes even late modernism or neomodernism. ${ }^{4}$ The distinction is a slippery one, obviously because there are various possible readings of his works. However, his two latest novels, The Childhood of Jesus and especially The Schooldays of Jesus incorporate, probably for the first time, mythical and fantastic elements and this is worthy of our attention insofar as it constitutes a new practice and innovation in his literary career, revitalising, again, the literary genre, as he has been doing since he published his first novel in $1974 . .^{5}$

The Schooldays of Jesus is the sequel of The Childhood of Jesus. It is possible to read one without the other, but the plots of the two novels obviously complement each other. They are written in a historical present and narrated with the misleading 


\section{The Limits of Reason in J.M. Coetzee's The Schooldays of Jesus}

simplicity of a fable. They imagine a society with no discernible past, a community governed by apparent goodwill, where three characters try to learn how to behave as an unconventional family, although they never really become one. In The Childhood of Jesus Davíd and Simón have come from far away on a boat they disembark from together. They have been "immersed in the waters of forgetting" (Coetzee 2013: 206) and all their memories have been washed away; Simón has no recollection of what his own life was before arriving in this new place and even his own mother tongue is forgotten. Davíd, a timid child at first, apparently became separated from his mother during the voyage and Simón takes him under his wing; he decides to become his guardian for the time being, find his mother and reunite the child with her.

Their destiny, a Spanish-speaking city named Novilla, provides food, shelter, employment and even affordable entertainment for all new arrivals. They also get new names, since Simón and Davíd cannot remember their previous ones, and an approximate age is written down in their documents. Both have been learning Spanish and still have to improve their command of what is for them a new language. The Childhood of Jesus plunges us into a mysterious dreamlike territory. The setting is a limbo where people have been expunged of their desires; they need no meat and no sexual intercourse, nor are passions ever described. The place evokes the Christian idea of Heaven and, to a certain extent, the city Plato describes in The Republic; in fact, "philosophical disputes take up space in nearly every chapter, and almost word-for-word references to a number of Socratic dialogues are easily detected through the book" (Mosca 2016: 128). Besides, Simón enrols in a philosophical course where they discuss the "sillicidad" (Coetzee 2013: 122) of a chair, ${ }^{6}$ and this reminds us of Plato's Theory of Forms, where he explains that a chair is only a physical object, an imperfect variation of the ideal chair that exists in the World of Forms. Simón, who constantly tries to explain the world to Davíd in a rational way, tells him at some point: "We are like Ideas. Ideas never die" (133). ${ }^{7}$ Surprisingly, Novilla, notwithstanding its heavenly features, becomes some sort of purgatory for Simón, who craves for passion and is unable to find it:

Everyone I meet is so decent, so kindly, so well intentioned. No one swears or gets angry. No one gets drunk. No one even raises his voice. You live on a diet of bread and water and bean paste and you claim to be filled. How can that be, humanly speaking? Are you lying, even to yourselves? (30)

As Dimitriu points out, “an untrammelled rationality of goodwill and kindness, instead of invoking our admiration, points to an almost surreal split between mind and body, or reason and emotion" (2014: 71). Despite the promise of peace and tranquillity, Simón has difficulties adapting to this new place. While he understands what this new life has to offer, he is concerned about the consequences of such a 


\section{Patricia Álvarez Sánchez}

choice, for “it involves stilling the 'hunger' of passion, or closeness of physical intimacy" (Dimitriu 2014: 71).

The main intertexts, as in previous novels, refer to Goethe, Kafka and the ubiquitous Cervantes. ${ }^{8}$ This tribute to the Spanish writer is more than evident in The Childhood, where Davíd carries around an abridged copy of Don Quixote and learns to read from it, but also in The Schooldays, which begins with an epigraph from the Spanish novel: "Algunos dicen, nunca segundas partes fueron buenas" (my translation: “some people say: Second parts were never good”). Coetzee's story also engages in a literary dialogue with The Bible, ${ }^{9}$ which is obvious in some of the passages and in the names of most characters. Although the title refers to Jesus, the novel is about Davíd, a gifted and self-confident child, but the biblical connection is still obvious. ${ }^{10}$ Indeed Simón, the main character, is (like Joseph) not the real father of the child, but a guardian figure who has symbolically adopted him and cares for him. When Simón locates a woman he believes to be Davíd's mother, she, mysteriously, agrees to become (or act like) his mother. Inés, however, never recognizes the child nor does she show a particular attachment to it. She is described as a self-indulgent and whimsical woman who later becomes an unprepared and overprotective mother. Davíd grows insecure under her protection. ${ }^{11}$ Moreover, she is not fully developed as a character in the novel, and she seems to be a character of secondary importance in the story.

Davíd and his so-called surrogate family, Simón and Inés, flee Novilla because of a census and the possibility that the non-compliant Davíd, the child who becomes rebellious and disruptive at school, may be sent to a reformatory. The reason is that he is not adapting to school; instead of reading children's books, he prefers to recite fragments from Don Quixote; in mathematics he is unable to do additions because he somehow uses abstractions of numbers, but not real ones. While, significantly, Simón is pursuing rational questions, and this is significant in my interpretation, Davíd grows obsessed with the idea that numbers are magical and have secret meanings. ${ }^{12}$ His teacher does not know how to deal with a child who does not conform to his dictates and teaching methodology. This is somehow a paradox because the setting is a place where everyone seems to be happy and lives, although austerely, in a sort of ideal socialist society where no one exerts power over anyone else.

\section{The Limits of Reason in The Schooldays of Jesus}

At the beginning of the sequel, The Schooldays of Jesus, the three protagonists are on their way to a different city called Estrella (star in English). While both The Childhood and The Schooldays tell the story from the perspective of Simón in a place 


\section{The Limits of Reason in J.M. Coetzee's The Schooldays of Jesus}

where all characters experience a different reality to what we would consider objective, The Schooldays incorporates many magical elements and it is anchored in "an almost surreal milieu" (Dimitriu 2018: 55) without a recognisable historical past, but one which possibly also reads as a pre-story to The Bible, the most famous religious myth in some of our Western societies. The story of The Schooldays is full of symbolism and spirituality, and its plot acknowledges that magic, as a symbol for irrationality, is part of our lives and includes telepathy, a woman of unearthly beauty, and a beast-man whose impulsive behaviour is foreshadowed by a rainstorm.

In The Schooldays, Inés and Simón initially become labourers on a fruit farm, where all their needs are fulfilled and the child seems to blossom. The farm is owned by three elderly sisters who develop a deep affection for Davíd and decide to support the family financially. When Inés and Simón start to worry about Davíd's education, Señor Robles, a private tutor, offers to reveal the basics of mathematics to the boy, but right after their first brief encounter, he insists that Davíd should learn in a rational way. As the child cannot learn as he is expected, the teacher comes to the conclusion that he has a cognitive problem, upon which they all become disappointed and decide to stop the tutoring. Education becomes an obstacle for the family not because the intelligent child does not want to learn, but because he does not adapt to the teacher's expectations. From among the many other novels that relate to this subject, it is tempting to single out Robert Musil's The Confusions of Young Törless (1906), since the Austrian author is one of Coetzee's main literary influences, one whom he has included in his Biblioteca personal, ${ }^{13}$ a collection of the works that have influenced him most. In this book, the young Törless is sent to a military academy where he, together with two other boys, sodomises a fellow student. The novel illustrates the devastating consequences of authoritarian education systems and their contribution to the rise of Fascism. Several passages are dedicated to mathematics, thus providing an interesting subtext to The Schooldays. Indeed Musil's Bildungsroman develops the idea that mathematics is duplicitous. On the one hand, viewed through the eyes of reason, mathematics appears to be accurate and sure; its results indicate something solid. It is, however, capable of going beyond reason, revealing its wild and unsettling nature, as when the young man is confused by his contemplation of the height of the sky and he becomes aware of his inability to capture its enormity. On a different occasion, Törless has a conversation with his maths teacher because he is interested in understanding imaginary numbers. His questions reveal his doubts as to whether numbers are human inventions or if they exist on their own. Coetzee's dialogue with Musil's reflection serves to highlight the more irrational aspect of mathematics, a discipline that we, from the Enlightenment onwards, have usually understood as solid and rational. In The Schooldays, it is evident that the maths tutor's disappointment is motivated by the child's interest in understanding mathematics in an irrational way. 
The small family later moves to a town called Estrella, where Inés and Simón get a job and decide to send the child to a dancing school, run by Señor Juan Sebastián Arroyo (Johann Sebastian Bach's name translated into Spanish) and the enigmatic Ana Magdalena, a woman Simón feels immediately captivated by. This attraction is probably based on the mystery she represents. Ana Magdalena is described as a graceful spirit with clairvoyant powers. Simón says that her skin is as pure as alabaster and he is astonished when he realises twice that she actually sees through him. Ana Magdalena was in fact Johannes Sebastian Bach's second wife in real life as well as in the novel. Another similarity is that she raised the children her husband had with his first wife. Their marriage had, again as in the novel, music at its heart. At the end of her classes the fictional Ana Magdalena makes an "arc sound" (Coetzee 2016: 60) and the children have to get in harmony with it; what she is actually using is a tuning fork, a musical instrument which produces a single note and which is believed by some to facilitate balancing, by bringing a positive shift in energy patterns and dissolving negative energy. Coetzee seems to have been influenced by Schiller's Romantic idea of beauty when he depicted Ana Magdalena, who is the reincarnation of both beauty and moral values. When she first meets Simón, she explains to him that she and her husband train the soul in the direction of the good. For Schiller beauty can be achieved only in the combined embrace of duty with a recognition of moral values. Ana Magdalena represents this and is described several times as a woman of unearthly beauty; in Simón's words she is "strikingly beautiful [...], the beauty, as if a statue had come to life and wandered in from the museum" (Coetzee 2016: 43). He also says that he "could spend hours gazing at her, rapt in admiration at the perfection she represents" (93), for she is a combination that results in a genuinely beautiful soul.

Coetzee has expressed his recognition and admiration for Johann Sebastian Bach several times. In an interview with Peter Sacks, he compares Beethoven with Bach, mentioning the former as the epitome of the artistic genius and the latter as an example of perseverance, to which he himself feels more related (Coetzee 2001). But he also declares that there is always a mysterious moment in the improvisation of Bach's musical compositions and portrays Arroyo in The Schooldays as a virtuoso with "his head in the clouds" (Coetzee 2016: 55), probably connecting this with Bach's religiosity. Coetzee explains the impact Bach’s music had on him when, back in 1955, he first listened to his Well-Tempered Clavier from a neighbour's house:

Is there some non-vacuous sense in which I can say that the spirit of Bach was speaking to me across the ages, across the seas, putting before me certain ideals; or was what was really going on at that moment that I was symbolically electing high European culture, and command of the codes of that culture, as a route that would take me out of my class position in white South African society and ultimately out of what I must have felt, in terms however obscure and mystified, as a historical dead end $[\ldots]$ ? (Coetzee 2002: 10-11) 


\section{The Limits of Reason in J.M. Coetzee's The Schooldays of Jesus}

This passion is also evident in Diary of a Bad Year (2007), ${ }^{14}$ where Señor C, a distinguished writer, airs his opinions on different matters, including this beautiful thought:

The best proof that life is good, and therefore that there may be perhaps a God after all, who has our welfare at heart, is that to each of us, on the day we are born, comes the music of Johann Sebastian Bach. It comes as a gift, unearned, unmerited, for free. (Coetzee 2007: 221)

In the character of Juan Sebastián Arroyo, Coetzee incorporates a passion for spirituality; the musician is, as it happens, an expert in numerology, a discipline he and Ana Magdalena teach the children at their school. Numerology is associated with astrology and similar divinatory arts. It is the belief in the divine and mystical relationship between numbers (also names) and coinciding events. The relationship between names and numbers had already been established in The Childhood: "You know how the system works. The names we use are the names we were given there, but we might just as well have been given numbers. Numbers, names - they are equally arbitrary, equally unimportant" (2013: 274). Again, the importance of names and naming is obvious in all Coetzee's novels. In fact, in one of his letters to Paul Auster, Coetzee expresses a sense that: "your name is your destiny" (Auster and Coetzee 2013: 79). Bach is known to have been a devout Lutheran and to have tried to give God's word a previously unknown profundity. He believed that the reason for music should be the glory of God; his compositions are probably the most performed music in religious rituals in Western culture. He is also supposed to have been a follower of numerology and to have believed in the mystical values of numbers; he, among other Baroque composers, used numbers instead of letters and incorporated them as well to convey hidden messages in his musical works. ${ }^{15}$ In The Schooldays, Arroyo and Ana Magdalena make a distinction between what they call "ant numbers" (Coetzee 2016: 69) and a different kind of numbers, those which may bring us closer to our true self, which is, again, a nod to Plato's World of Forms. The Academy of Dance where Davíd is enrolled suits the child perfectly because he likes being taught in an unconventional way; indeed the children learn through dancing; for example, in order to learn the numbers, they dance to call them down from the sky. This is, to say the least, a very alternative teaching methodology, but in fact, the connection between numbers, stars and music is an old one. It takes us back to Pythagoras who believed that the spheres of the universe produce music based on their orbit (Hermann 2004: 101), though unfortunately it is one that remains imperceptible for human beings. This idea that the planets, as they travel through space, generate a celestial harmony of profound beauty, known as the Harmony of the Spheres, was also mentioned in Plato's Republic and later endorsed by many humanists of the Renaissance. ${ }^{16}$ 


\section{Patricia Álvarez Sánchez}

In The Schooldays, Coetzee presents the reader, through the character of Davíd, with some of the ideas of Pythagoras, who is considered the founder of numerology (Hermann 2004: 107). Many scientific discoveries are attributed to him, including advances in the fields of music and astronomy. It is probably not a coincidence that Davíd, like Pythagoras, believes in reincarnation. The child repeatedly insists that there are different worlds: "I can remember the time before I was on the boat" (Coetzee 2016: 17). He even comes up with an idea for moving back and forth between them that evokes the myth of Theseus and the Minotaur:

I found a way of coming back from the new life. Shall I tell you? It's brilliant. You tie a rope to a tree, a long, long rope, then when you get to the next life you tie the other end of the rope to a tree, another tree. Then when you want to come back from the next life you just hold on to the rope. Like the man in the larebinto. (206, emphasis in original)

Pythagoras was supposed to know not only who he was himself, but also who exactly he had been in his past lives (Ferguson 2011: 51). Davíd incarnates this idea when Arroyo tells Simón: "What he remembers I cannot say but it includes what he believes to be his name" (Coetzee 2016: 215). Pythagoreans elaborated on a theory of numbers, the exact meaning of which is still debated among scholars. Pythagoras also set up a philosophical school in Croton, where he became reputable and was credited with miracles. According to Russell, this school represents the main current of a mystical tradition we have set in contrast with the scientific tendency (1972: 32). This educational centre promoted ascetic practices (many of which had a symbolic meaning), various religious theories and vegetarianism (De Vogel 1966: 177). Songs were produced and sung at this school, and these were believed to have the ability to make the soul evolve towards positive passions and even to heal them: “It was Pythagoras' opinion that certain rhythms and melodies had a healing effect on the human character and emotions: it restores the soul's strength to its original balance [...]. Dancing was also used as a therapy" (De Vogel 1966: 164-65).

The Pythagoreans exercised an important influence on the work of Plato and other philosophers; for example, Socrates, Plato's teacher, believed that music was a gift that brings harmony to our souls and that a true musician is someone who harmonises his own personality and his own life (Pelosi 2010: 185). The Platonic Republic might be related to the idea of an organised community of like-minded thinkers, ${ }^{17}$ like the one established by Pythagoras in Croton. There is evidence that Plato possibly took from Pythagoras the idea that mathematics and, generally speaking, abstract thinking, is a secure basis for the philosophical cosmos. Plato and Pythagoras shared a spiritual approach to the soul and its place in the material world. In The Laws, Plato's longest dialogue, the Greek philosopher exalts the 


\section{The Limits of Reason in J.M. Coetzee's The Schooldays of Jesus}

merits of a musical education as it represents an expressive exercise in which one may learn to love beautiful things. It also deals with what Plato calls "the 'magical' power of mousike" (Pelosi 2010: 26), meaning that music influences our character. Moreover, music is supposed to reach out equally towards the rational and nonrational components of the human soul.

The idea at Arroyo's Academy of Dance is that children are part of the universe and can be taught to communicate with it, rather than just memorise ideas from books. This is probably a nod to Socrates, who argued that education should not be understood in terms of forcing knowledge into another person but rather as turning the whole soul around (in Lear 2010: 70, emphasis in original). This scheme of leaving rationality behind has, to a certain extent, mystical implications. The use of vocabulary in The Schooldays is traditionally associated with the spiritual world: the concepts of soul —one of the sisters' names is Alma (soul in Spanish) but also beauty, goodness and goodwill, grace and gratitude, magic, the stars and the universe belong to this lexeme. Señor Arroyo makes this explicit when, trying to explain his teaching philosophy, he quotes some lines from one of Rafael Alberti's poems: "Las estrellas errantes, niños que ignoran la aritmética" (Coetzee 2016: 97; my translation: "wandering stars are children ignorant of arithmetic"). ${ }^{18}$

Arithmetic, thus, symbolises rational thought, in what again comes across as a critique on authoritarian education systems. Indeed, as a young child, the Spanish poet attended a Jesuit school where he became rebellious and played truant until he was expelled in 1917.

Simón (like Inés, although she never really attempts to understand this) is quite sceptical about the teaching methods and contents offered at the Academia. He reflects: "Dancing to the stars as a substitute for learning one's multiplication tables - is not different in nature from what is offered by the lotion that miraculously brings hair follicles back to life" (Coetzee 2016: 66). He thinks of himself as a rational and logical person who offers the child a sane, rational explanation of the world, but he is also a sceptic who includes his own certainties in his questioning so that he finally wonders: "Are the needs of a child's soul better served by his dry little homilies than by the fantastic fare offered at the Academy?" (207).

Dimitriu points out that Plato presented his ideal of human harmony as a balanced synthesis of the three aspects of the soul: reason, spirit and appetite, and that in The Schooldays they exist as separate entities (2018: 56). While Simón represents reason and Davíd spirit, there is a third character that can be interpreted as appetite, desire and passion. Indeed, passion and its consequences also play a crucial role in the novel. The passionless Estrella seems, like Novilla, to be governed by goodwill. The crime report page in the local newspaper tells the story of a lawnmower being stolen from an unlocked shed, but there is a new element that disturbs the peace 
of the town, a despicable character called Dmitri. He is a worker for the art museum next to the Academy and a man who is obviously infatuated - one could say obsessed- with Ana Magdalena. Depicted as an anti-hero, from Simón's perspective, he is always untidy, smells of cigarettes and has yellowed teeth. Simón considers him to be a bad role model for children: "This man doesn't shave, doesn't wash, he doesn't wear clean clothes. He is not a good example to children" (Coetzee 2016: 47). He believes that he has no inner noble qualities, the kind that one would find and are exalted in Don Quixote, who is honest, capable of sincere gratitude and epitomises courtesy. Moreover, it is no coincidence that Dmitri has a Russian name. He is a nod to Dostoyevsky's definition of guilt and a very similar character with the same name appears in The Brothers Karamazov (1880), a philosophical novel concerning faith, doubt and reason, which is replete with ethical debates about free will, morality and the existence of God.

One possible interpretation is that the triangle (Davíd, Dmitri and Simón) "displays a conglomerate of traits that could constitute a perfect human being: a mix of reason, imagination and daring" (Dimitriu 2018: 56). But it is also worth pointing out that Dmitri can be interpreted as Simón's doppelganger (they represent opposite views of the world) and the influence they exercise on the boy is an important theme in the novel. The characterisation of Simón gives pride of place to his intelligence and capacity for rational judgement. He takes philosophy classes and elaborates complex theories about how the world works. By contrast, Dmitri says of himself: "When it comes to life's great choices, I follow my heart" (Coetzee 2016: 119). Similarly, the Dmitri Dostoyevsky portrayed in his novel represents the principle of feeling, sensuality and the inspiration of Eros (Mochulsky 1981: 16). However, to his own discontent, the sceptical and rational Simón recognises in Dmitri a model for passion which he also somehow finds himself unwillingly attracted to. Dmitri is the source of dramatic energy in the novel, and the harbinger of bad luck. Davíd, who has become blissfully happy at the Academy, forms a particular bond to the beautiful Ana Magdalena, but also becomes mesmerised by the grandiloquent Dmitri. At some point in the novel, Ana Magdalena disappears and Dmitri confesses to the authorities that he has raped and strangled her. Unfortunately, it is the boy who finds her bruised dead body in the museum where Dmitri works. Estrella suddenly becomes a sinister place.

Simón and Dmitri also represent two different masculinities and parenting examples. The subject needs more development to give it its due importance in the novel. Simón, who had repeatedly insisted that the child was neither his son, nor his grandson in The Childhood, claims his paternity for the first time when he talks to Dmitri about the pornographic magazines he keeps: "I want you to stop inviting Davíd, my child, the child for whose welfare I am responsible, into your room and 


\section{The Limits of Reason in J.M. Coetzee's The Schooldays of Jesus}

showing him dirty pictures" (Coetzee 2016: 120, emphasis added). As Dimitriu argues, The Schooldays focuses on Simón's role as the father of an unusual child (2018: 56). But at the same time, it also shows several instances of Dmitri pretending to be the boy's father and trying to take control of his life; for example, he constantly tries to convince Davíd that the two of them could live together with Ana Magdalena as a family in the next life. The boy believes in this possibility. When he wants to escape from the psychiatric wing where he has been sent, Dmitri puts on a uniform, takes Davíd's hand (he is there to visit him), claims to be his father and, surprisingly, succeeds in absconding. Later on, when he goes to Simón's apartment, he makes himself at home, sleeps in his bed, wears his clothes and says to the child: "Do you have anything to eat, my boy?" (169, emphasis added) and later: "Never mind, my son" (169, emphasis added). The relationship between Dmitri and the Davíd becomes so evident that Simón fears that the boy may be attracted to Dmitri, who obviously represents a more attractive and even magnetic paternal figure. The rational Simón explains to Davíd that the passionate Dmitri is, in fact, incapable of true love. The boy becomes, under Dmitri's guidance, restless, insensitive and even tyrannical, at least in Simón's opinion, and this change is indeed acknowledged by the three sisters.

Simón's and Davíd's views of the world are irreconcilable. Simón wishes to untangle the world for Davíd and give an answer to his endless "why" questions, but his explanations never really satisfy the boy. His adult perspective is too philosophical and sometimes contradictory. For example, talking about money, Simón says: "There is no such a thing as a lot of money in itself" (Coetzee 2016: $50)$. His views of the world are sometimes conservative. When Davíd asks him why he and Inés do not have a child, he answers: "Sexual intercourse is for married people. Inés and I aren’t married" (17). On the other hand, Simón does not listen to the child and provides readers with a limited version of the story. ${ }^{19}$ Although the reader encounters a third-person narrator, the whole story is focalised through Simón and it is clear that the narrative is presented from his perspective; it is his consciousness and experiences that we have access to. Davíd insists that he knows who he is and that other characters, such as Arroyo, recognise him; Arroyo even tells Simón that Davíd feels the falsity of his new life quite intensely, but Simón constantly denies that such may be the case. He tells the child: "Like everyone else who came on the boats, you can't remember" (18).

Davíd is characterised as an idealist and it is important to note that he always carries a copy of Don Quixote, which he uses to teach himself to read, and later carries it to all his classes at the Academy. Davíd's behaviour resembles that of Don Quixote in that he is an idealist and has innate noble qualities. Another parallelism between them is that they both have a real and an imaginary name, as not Don 
Quixote, but Alonso Quijano, was this character's original name. Moreover, both characters search and find artistic expression for their restlessness and ambitions; Don Quixote sings well and composes verses, while Davíd becomes the best dancer at the Academia. In the Spanish classical novel, and so for Don Quixote, chivalry means defending the weak, as Davíd previously does when he tries to save an injured duck on the farm. There is, however, a tension between those virtues and the eccentricity manifested by their defenders. Davíd becomes impatient and whimsical if he is not given what he wishes to have or told what he wishes to hear. Don Quixote goes mad whenever knight-errantry is questioned. Despite their extravagance, both the Spanish caballero errante and Davíd provide examples of how we can set our imagination free and discover new qualities within human beings.

In his relationship with the child, Simón represents the voice of the practical realist. He explains that Davíd "believes he has powers he does not really have" (Coetzee 2016: 73). Davíd considers philosophical questions in relative depth and embodies the exploration of the nature of truth, justice and virtue with the clarity and innocence one can only achieve if looking through the lenses of irrationality and fantasy. For example, when the boy asks why we eat animals, Simón explains that animals are happy to die for us so that we can grow and be healthy; then the child asks why we do not eat other human beings. Simón's answer is that we do not "because it is disgusting" (77), but of course for a vegetarian, such as Coetzee, this is also a good enough reason for not eating animals. Davíd thus represents the struggle to survive in a world of rationality with the assumptions of a child, a world Simón, a supreme realist, feels he understands better.

There is, however, a deeper tension apparent in their discussions. Coetzee's novels have shown a deep ambivalence towards rationalism; to borrow the words from the Swedish Academy when he was awarded the Nobel Prize for Literature, his stories often criticize the cruel rationalism and cosmetic morality of our western civilization. For instance, there is an implicit criticism of modern rationality in the economic and social structures that make possible the killing of millions of animals for human consumption, as Costello argues in her homonymous novel, and several of Coetzee's characters - for example, Eugene Dawn in "The Vietnam Project" (1974), the Magistrate in Waiting for the Barbarians (1980) and Paul Rayment in Slow Man - offer a critique of the individualist and insensitive Cartesian self and thus show different forms of psychological suffering and disintegration. In The Schooldays, Coetzee goes even further and offers us a protagonist, Simón, who is the epitome of rational thought and shows the consequences of his attempts to exert his influence in a world full of symbolism and spirituality; while he tries to explain the world in rational terms, Davíd clings to his fantasy universe and is 


\section{The Limits of Reason in J.M. Coetzee's The Schooldays of Jesus}

unwilling to accept his foster father's answers as universal truths. His explanations about the world fail on a variety of grounds: clearly, they do so because he, as the father figure, is trying to impose his adult language and his imaginary world on the child, but also because the latter is never satisfied with a simple answer, so that each explanation triggers the next more complex question and no answer ever really reveals an hermeneutical truth that may seem complete. Despite Simón's efforts to communicate with the boy, his distress at the development of their relationship becomes obvious in the writing assignments he produces for a composition class, but also in his conversations with Arroyo and the letters he plans to send to him. However, Ana Magdalena had already given Simón a very important idea at a parents' meeting, where she explained that children lack the words to express their former lives, but they can rely on numbers and dance to express themselves:

Of our former existence certain remnants persist: not memories in the usual sense of the word, but what we call shadows of memories [...]. The child however, the young child, still bears deep impresses of a former life, shadow recollections which he lacks words to express. He lacks words because, along with the world we have lost, we have lost a language fit to evoke it. All that is left of that primal language is a handful of words, what I call transcendental words, among which the names of numbers, uno, dos, tres, are foremost. (Coetzee 2016: 67-68, emphasis in original)

This idea of music and dance being a powerful universal language already appeared in Coetzee's novel Foe (1986) where Susan, the protagonist, tries to make the mute Friday tell his story, but he fails to do so. At the end of the novel Friday starts playing a musical instrument, and she ponders: "As long as I have music in common with Friday, perhaps he and I will need no language" (1986: 97). Another very interesting observation comes from Lurie in Disgrace when he says: "His own opinion, which he does not air, is that the origins of speech lie in song, and the origins of song in the need to fill out with sound the overlarge and rather empty human soul" (1999: 4).

According to Simón, whose perspective and story are relayed by the narrator, Davíd has never allowed him to see him dance because the boy feels, metaphorically, that his surrogate father is hostile to the numbers. However, when Simón listens to the music Arroyo plays at the parents' evening, he "falls into a mild trance" (Coetzee 2016: 70). Looking for answers, he visits the Academia once more and finds Arroyo composing. He stops to listen and finally abandons himself to the music, so that at this moment he frees himself from rationality and questions the limits of his own self; hence his soul begins to dance:

He gives himself to the music, allowing it to enter and wash through him. And the music, as if aware of what is up, loses its stop-start character, begins to flow. At the very rim of consciousness the soul, which is indeed like a little bird, emerges and shakes its wings and begins its dance. (194) 
Simón has finally experienced the magical power of mousike; he has learnt that reason, in its unadulterated form, is not enough to understand the world.

\section{Conclusion}

This article has striven to show that The Schooldays follows a new path in Coetzee's oeuvre. While most of Coetzee's novels are set in societies riven by different forms of institutionalized discrimination (Apartheid or post-Apartheid South Africa, and other allegorical colonial or postcolonial societies), his latest novel incorporates mythical and religious elements in an otherwise apparently realist setting, a place which seems to be governed by goodwill. Moreover, it not only focuses even more on ethical and philosophical questions, it also offers, for the first time, a significant and intense dialogue with classical philosophers. Following them, The Schooldays combines constant spiritual allusions with an examination of the character of human existence and an implicit critique of rationalism. Coetzee shows that scepticism towards rationality can help us discover compassion, generosity and, finally, grace. Similarly, the novel explores a sceptical view of uncontrolled passion; neither the logical Simón nor the passionate Dmitri are good models to explain the world in itself and both of them provide inadequate parenting examples. While Simón and Dmitri represent the influence of reason and passion on a human being, Davíd, a singular child, untouched by civilisation and language, and an idealist like Don Quixote who shares many of his inner qualities, stands for a pure soul, one that listens to the music of the spheres and who claims that he can perceive it.

When Davíd dances the last time, the rational Simón is able to see that the child becomes "pure light" (Coetzee 2016: 246), and finally starts to understand the child's language and the magic of music. It is through the irrational influence of music and dance that Simón experiences this final change. In the last chapter, he decides to take dance lessons, buys golden dancing slippers and finally dances to Arroyo's music. While he is balancing, he becomes aware of "the space above his head" (260) and the first star begins to rise over the horizon. In this effort to communicate with Davíd, a pure soul, and through the impact music has on him, he has acknowledged the limits of reason as a tool used to make sense of our lives. Rational Simón has not been able to become a proper father to the child, but the boy, with his vision of the world, has exerted his own influence on Simón, helped his surrogate father, the lost child, and readers as well, learn the most important lesson of all, maybe that we are all part of an immense universe which we cannot control nor completely grasp in rational terms, and that music helps to make it a more beautiful place and comes, unmerited, as a gift to all of us. ${ }^{20}$ 


\section{Notes}

1.While Pippin argues that Coetzee's novels are more informed by philosophy, especially by the work of Hegel and Nietzsche, than those of anyone now writing (2010: 22), Leist and Singer concur that Coetzee's oeuvre is deeply philosophical for its unusual degree of reflectivity where a deep-layered intellectual attitude of paradoxical truth seeking and an ethics of the social come together (2010: 6-7). Similarly, Dimitriu, who has recently analysed The Schooldays of Jesus, suggests that one can approach it as Coetzee's most daring novel of ideas (2018: 65)

2. Siete cuentos morales (Moral Tales) was published in Spanish first.

${ }^{3}$. The first one is called the divine realm of immutable Forms and it serves as a model for the second one, a realm in which humans live and matter is constantly changing, ruled by passions (Ferguson 2011: 138).

${ }^{4}$.It is sometimes said that postmodernism arrived in South Africa with the publication of Dusklands in 1974 (Head 2009: ix) and most critics consider Coetzee a postmodernist writer because of his use of metafiction and non-realist devices and his engagement with political questions. Moreover, Coetzee has relied on major developments in the European novel since the nouveau roman while developing his own ethical and political response to South African institutionalised inequality and oppression. Therefore, Hutcheon considers Coetzee a postmodernist (1989: 51, 76), and Attwell states that Coetzee's Foe (1986) typifies postmodernism (1993: 20-23). However, Attridge believes that this term does not fit Coetzee's fiction -as his writings have been influenced by great modernist authors such as Beckett and Kafka (but not Barth or Pynchon) - and argues that Coetzee "extends and revitalises modernist practices" (2004: 6). He prefers the label "late modernism or neomodernism" (2004: 2-3), although he also states that these terms are not completely appropriate either.
${ }^{5}$. In this sense, it is relevant that Coetzee mentions in one of his letters to Auster: "It is not uncommon for writers, as they age, to get impatient with the so-called poetry of language and go for a more stripped-down style ('late style'). The most notorious instance, I suppose, is Tolstoy [...]. A loftier example is provided by Bach, who at the time of his death was working on his Art of Fugue, pure music in the sense that it is not tied to any particular instrument" (Auster and Coetzee 2013: 88).

${ }^{6}$. The novel uses some Spanish terms to remind us that this is the language which the characters use to communicate. The word sillicidad does not exist in Spanish, but it is meant to be the quality that distinguishes a chair from any other object.

${ }^{7}$. There is also, at least, one reference to another significant philosopher, Heraclitus, when Simón says: "The waters of the ocean flow and in flowing they change. You cannot step twice into the same waters" (Coetzee 2013: 144), as Heraclitus was known for his famous dictum "You cannot step twice into the same river; for fresh waters are ever flowing in upon you" (Russell 1972: 46).

8. Don Quixote is an important influence in Coetzee's novels as he has acknowledged in his "The Poetics of Reciprocity" where he writes: "Cervantes is the giant on whose shoulders we pigmies of the postmodern novel stand" (1992: 62).

9 . There are previous references to religiosity in Coetzee's novels. For instance, David Lurie sacrifices his favourite dog at the end of Disgrace (1999). The imagery of the sacrifice calls attention to the religious dimension Davíd's development has acquired as a consequence of his connection with animals. Another example is Michael $\mathrm{K}$ in Life \& Times, who grows pumpkins on the same spot where he has buried his mother's ashes. When the first plant grows, he eats it and his words "for what we are about to receive make us truly thankful" (1983: 113), are reminiscent of the ritual of the Eucharist. 


\section{Patricia Álvarez Sánchez}

10. There are also striking parallels between Pythagoras' and Jesus' lives, probably due to the influence of Pythagoreanism in Platonism and later in Christian philosophy.

11. There are also several suggestions in the novel that she is a virgin, which would make it impossible for her to be Davíd's mother. The name Inés means holy and chaste, possibly in reference to her virginity. Simón wonders: "May she indeed be [...] a virgin or at least the virginal type?" (Coetzee 2013: 103).

12. This is not the first time mathematics and numbers are linked to irrationality in Coetzee's fiction. The eponymous protagonist of his 2003 novel, namely Elizabeth Costello, mentions Srinivasa Ramanujan, an Indian mathematician who died prematurely at the age of thirty-three, and who was, according to her, an example of a genius whose mind was probably closer to God because of his mathematical vision.

\section{His Biblioteca personal} includes novels and essays by eleven writers and a collection of his favourite poems and it was published in Argentina in Spanish first. Musil's Tres Mujeres and Uniones (Three Women and Unions) are part of it.

14. Some critics have commented on the layout of the novel that offers three related stories that appear to be visually separated, divided by a continuous line, on every page. For example, Tonkin (2007) refers to the organisation of the text as a "hypertextual polyphony" in his review of the novel and Whatley compares the novel's form to Bach's music: "The ensemble nature of the sections comes to resemble musical parts. Were each section read linearly, across to the end and then beginning again twice, it would be like hearing just the woodwinds, then the strings, and finally the percussion" (2008).

15. For example, Bach was obsessed with number 14, which appears throughout his work. The reason for this seems to be that if we change letters to numbers, his name $\mathrm{BACH}$ would translate 2+1+3+8=14 (Rogerson 2013).

16. It appears for instance in Shakespeare's The Merchant of Venice when Lorenzo explains to his wife Jessica that the spheres of the universe are the origin of the heavenly music that only the cherubins can hear.

17. In The Republic Plato imagines the future Guardians, those who can grasp the Forms and rule, to be exposed to music from a young age so that they may acquire important moral habits. In Coetzee's novel, some of the students who perform at the parents' evening wear a white toga that leaves one shoulder bare and are reminiscent of them.

18. Alberti also appears in Coetzee's Biblioteca personal selection of poetry.

19. In the one lesson Davíd has with Señor Robles, the teacher tries to make him learn what the Arroyos later call the "ant numbers" (Coetzee 2016: 69), numbers that we use to count things in everyday life, but those which do not take individuality into account. Davíd, not wanting to comply with this requirement, shows to Simón that he can add and subtract numbers quite easily for a child of his age though he did not mention this for the following reasons: in Señor Robles' way "you first have to make yourself small. You have to make yourself as small as a pea, and then as small as a pea inside a pea, and then a pea inside a pea inside a pea" (32). However, Simón feels disappointed with him and later gives the teacher a present.

20. While I started writing this article, I participated in "Coetzee's Women Conference" hosted by Monash University in Prato. Some of the scholars who met there felt the need to continue discussing Coetzee's fiction, especially his latest novel and thus, "The Prato J.M. Coetzee reading group" was created. I am grateful to this group for the insight and inspiration provided through the common reading of the novel. Its members are: Michael Deckard, Jana Giles, Lucy Graham, Agata Szczeszak-Brewer, Aparna Tarc and myself. 


\section{Works Cited}

AtTRIDGE, Derek. 2004. J.M. Coetzee and the Ethics of Reading. Chicago: University of Chicago Press.

Attwell, David. 1993. J.M. Coetzee: South Africa and the Politics of Writing, Berkeley: University of California Press.

Auster, Paul and J.M. Coetzee. 2013. Here and Now: Letters (2008-2011). New York: Penguin.

Cervantes, Miguel de. (1605) 2004. The History of the Valorous \& Witty Knight-Errant Don Quixote of the Mancha. Trans. E. Grossman. London: Secker and Warburg.

Coetzee, J.M. 1983. Life \& Times of Michael K. London: Vintage.

Coetzee, J.M. 1986. Foe. London: Penguin.

Coetzee, J.M. 1990. Age of Iron. London: Penguin.

Coetzee, J.M. 1992. "The Poetics of Reciprocity". In Attwell, David (ed.) Doubling the Point. Point: Essays and Interviews. Cambridge: Harvard U.P.: 55-68.

Coetzee, J.M. (1974) 1996. “The Vietnam Project". Dusklands. New York: Penguin Books

Coetzee, J.M. 1999. Disgrace. London: Vintage.

Coetzee, J.M. 2001. "J.M. Coetzee with Peter Sacks". Interview with Peter Sacks. <http:// vimeo.com/12812247>. Accessed 3 July 2018.

Coetzee, J.M. 2002. "What is a Classic?" In Stranger Shores: Essays 1986-1999. London: Vintage: 6-19.

Coetzee, J.M. 2003. Elizabeth Costello. New York: Penguin

Coetzee, J.M. (1980) 2004. Waiting for the Barbarians. London: Vintage.

Coetzee, J.M. (2005) 2006. Slow Man. London: Vintage.

Coetzee, J.M. 2007. Diary of a Bad Year. London: Vintage.

Coetzee, J.M. 2013. The Childhood of Jesus. London: Vintage.

Coetzee, J.M. 2016. The Schooldays of Jesus. London: Penguin.
Coetzee, J.M. 2018. Siete cuentos morales. Buenos Aires: El hilo de Ariadna.

De Vogel, Cornelia. 1966. Pythagoras and Early Pythagoreanism: An Interpretation of Neglected Evidence on the Philosopher Pythagoras. Assen: Van Gorcum.

DIMıTRIU, Ileana. 2014. “J.M. Coetzee's The Childhood of Jesus: A Postmodern Allegory?" Current Writing: Text and Reception in Southern Africa 26 (1): 70-81.

DIMıTRIU, Ileana. 2018. “J.M. Coetzee's The Schooldays of Jesus (2016): A Novel of Ideas?" Current Writing: Text and Reception in Southern Africa 30 (1): 55-68.

DostoYevsky, Fiodor. 1880 (1981). The Brothers Karamazov. Trans. A.R. MacAndrew. New York: Bantan Books.

Ferguson, Kitty. (2008) 2011. Pythagoras: His Lives and the Legacy of a Rational Universe. London: Faber and Faber.

HEAD, Dominic. 2009. The Cambridge Introduction to J.M. Coetzee. New York: Cambridge U.P.

Hermann, Arnold. 2004. To Think like God: Pythagoras and Parmenides. Las Vegas: Parmenides Publishing.

Hutcheon, Linda. 1989. The Politics of Postmodernism. London: Routledge.

LEAR, Jonathan. 2010. "Ethical Thought and the Problem of Communication". In Leist, Anton and Peter Singer (eds.) J.M. Coetzee and Ethics: Philosophical Perspectives on Literature. New York: Columbia U.P.: 65-88.

LeIST, Anton and Peter SINGER. 2010. "Introduction: Coetzee and Philosophy". In Leist, Anton and Peter Singer (eds.) J.M. Coetzee and Ethics: Philosophical Perspectives on Literature. New York: Columbia U.P.: 1-18.

MARSHALL, John. (1891) 2016. A Short History of Greek Philosophy. New York: Philosophical Library.

MochULSkY, Konstantin. 1981. "Introductory Essay". In Dostoevsky, Fyodor. The Brothers Karamazov. Trans. A.R. MacAndrew. New York: Bantan Books: 5-20. 
MoscA, Valeria. 2016. "Ideas and Embodied Souls: Platonic and Christian Intertexts in J.M. Coetzee's Elizabeth Costello and The Childhood of Jesus". European Journal of English Studies 20 (2): 127-138.

MusiL, Robert. (1906) 2014. The Confusions of Young Törless. Trans. M. Mitchell. Oxford: Oxford U.P.

Pelosi, Francesco. 2010. Plato on Music, Soul and Body. Cambridge: Cambridge U.P.

PIPPIN, Robert. 2010. “The Paradoxes of Power in the Early Novels of J.M. Coetzee". In Leist, Anton and Peter Singer (eds.) J.M. Coetzee and Ethics: Philosophical Perspectives on Literature. New York: Columbia U.P.: 19-42.

Rogerson, Barnaby. 2013. "Bach and Gematia". The Guardian. <https://www. theguardian.com/books/booksblog/2013/ dec/14/books-advent-calendar-14-bachgematria> Accessed October 19, 2019.

RusselL, Bertrand. (1945) 1972. A History of Western Philosophy and its Connections with
Political and Social Circumstances from the Earliest Times to the Present Day. New York: Simon and Schuster.

Shakespeare, William. (1600) 2003. The Merchant of Venice. Cambridge: Cambridge U.P.

TonkIN, Boyd. 2007. "Beyond the Prophet Motive". The Independent (August 31). <http://www.independent.co.uk/artsentertainment/books/reviews/diary-of-a-badyear-by-jm-coetzee-463586.html>. Accessed November 10, 2017.

WhATLEY, Daniel. 2008. "Diary of a Bad Year by J.M. Coetzee". The Quarterly Conversation. $<$ http://quarterlyconversation.com/diary-of-abad-year-by-jm-coetzee-review>. Accessed October 12, 2017.

Woessner, Martin. 2010. "Coetzee's Critique of Reason". In Leist, Anton and Peter Singer (eds.) J.M. Coetzee and Ethics: Philosophical Perspectives on Literature. New York: Columbia U.P.: 223-247. 